Article

\title{
A Fluid Inclusion Study of the Brookbank Deposit, Northwestern Ontario: A Transition from Mesothermal to Epithermal Gold Deposition
}

\author{
Barbara Kowalski and Stephen Kissin * \\ Department of Geology, Lakehead University, Thunder Bay, ON P7B 5E1, Canada \\ * Correspondence: sakissin@lakeheadu.ca; Tel.: +1-807-343-8220 \\ Received: 9 October 2017; Accepted: 21 February 2018; Published: 1 March 2018
}

\begin{abstract}
The Brookbank and Cherbourg Zone gold deposits are located in the Beardmore-Geraldton greenstone belt of the Wabigoon Subprovince of the Archean Superior Province of the Canadian Shield. Brookbank is a shear zone deposit, whereas the Cherbourg Zone, joined by a shear zone to the Brookbank, is a fissure vein deposit, presumably formed by the same ore-depositing fluid. A total of 375 fluid inclusions, all with low salinity (generally $<1{ }^{\circ} \mathrm{C}$ freezing point depression) and presence of $\mathrm{CO}_{2}$, from the two deposits were studied. Cross-cutting relationships delineated three stages of vein formation: (1) pre-ore, (2) ore stage and (3) post-ore. Stage 1 inclusions homogenized at ca. $230{ }^{\circ} \mathrm{C}$ with low salinity, although at Brookbank a high temperature episode at ca. $360^{\circ} \mathrm{C}$ was noted. Stage 2 homogenized at ca. $266^{\circ} \mathrm{C}$ at the Cherbourg Zone and over a range $258-269^{\circ} \mathrm{C}$ with somewhat higher salinity. Eutectic temperatures indicate that the fluid composition was within the $\mathrm{MgCl}_{2}-\mathrm{NaCl}-\mathrm{H}_{2} \mathrm{O}$ system. Fluid immiscibility was prominent in that inclusions homogenized to liquid and vapor at the same temperature were observed. The majority of inclusions from Brookbank homogenized to vapor, whereas those from the Cherbourg Zone homogenized to liquid, marking the transition from mesothermal to epithermal lode gold deposition. Stage 3 fluid inclusions from the Cherbourg Zone homogenized at slightly elevated temperatures and contained fluid possibly representing metastable hydrates of $\mathrm{KCl}$. These post-ore fluids may have been the source of potassium feldspar alteration that overprinted earlier alteration assemblages.
\end{abstract}

Keywords: lode gold deposit; fluid inclusions; immiscibility

\section{Introduction}

The Brookbank deposit, currently under development by the Greenstone Goldmines Ltd. And Premier Goldmines Ltd. joint venture [1], is located in the Geraldton greenstone terrain of the Archean Superior Province of the Canadian Shield [2]. The deposit is located approximately $20 \mathrm{~km}$ northeast of the town of Beardmore, Ontario, at the western end of the Beardmore-Geraldton greenstone belt. This region, $100 \mathrm{~km}$ long and $40 \mathrm{~km}$ wide, has been the site of 18 gold mines operated at various times from 1934 to 1968, with a total recorded production of 128,000,811 gm of gold and 9,906,157 gm of silver [3]. The modern era of gold prices has brought about increased interest in the belt in terms of exploration and potential development.

The Brookbank deposit has a history of exploration for more than 70 years [4]. This study was undertaken while the deposit was held by the former Metalore Resources Ltd. and was considered to consist of two deposits, the Metalore deposit, a shear zone-hosted deposit, and the Golden Highway deposit, a fissure zone deposit located immediately to the west of the Metalore deposit. The two deposits are currently known as the Brookbank deposit and its Cherbourg zone, respectively. The Brookbank deposit has recently been assessed for its resource potential, yielding an indicated 
resource of $2.638 \mathrm{Mt}$ at $2.02 \mathrm{~g} / \mathrm{t}$ in open pit mining and $1.851 \mathrm{Mt}$ at $7.21 \mathrm{~g} / \mathrm{t}$ in underground mining [4]. The Cherbourg zone was previously assessed as a potential resource of $441,000 \mathrm{t}$ at $6.3 \mathrm{~g} / \mathrm{t} \mathrm{[5]}$.

The deposit is typical of lode gold deposits in an Archean setting, although other terms have been used; i.e., mesothermal gold or orogenic gold [6]. Both of the latter designations may be criticized as too general. Mesothermal, in this context, may be inaccurate in that the deposit may have formed under a number of temperature and pressure conditions. Although orogenic processes may be involved in genesis of the deposit, other gold deposits may also have formed in relation to orogenesis.

However, epithermal and mesothermal ore deposits as defined by the Lindgren classification [7] have utility if considered more generally with respect to the style of deposition regardless of the type of ore. Thus, epithermal thermal deposits can be formed at relatively shallow depths and low temperature, whereas mesothermal deposits can be formed at greater depths and higher temperatures without stipulation of specific temperatures and depths. The formation of shear zone-hosted deposits has been related to high-angle reverse faults formed in response to seismic activity [8]. The fault develops into a shear zone when the pressure of a fluid in the fault attains a pressure approaching lithostatic pressure. Seismic activity releases the fluid and causes brecciation, creating open space for ore deposition. This mechanism is proposed to be typical in mesothermal lode gold deposits [9].

Epithermal deposits may form in extensional stress regimes where dilational jogs between en echelon fault segments creates open space allowing for fluid flow. The space created results in the formation of fissure veins $[9,10]$, which in a more detailed discussion have been called extension veins [11]. Thus, according to the foregoing, mesothermal gold deposits characteristically formed in shear zones, whereas epithermal gold deposits formed in fissure veins.

The Brookbank shear zone deposit and the Cherbourg Zone fissure vein can be seen to represent mesothermal and epithermal deposits, respectively. This study was undertaken in order to determine the characteristics of the ore-depositing solution and the conditions under which ore deposition occurred. To this end 375 fluid inclusions were examined and interpretation of the data obtained was carried out [12].

\section{Regional and Local Geology}

\subsection{Regional Geology of the Beardmore-Geraldton Greenstone Belt}

The Beardmore-Geraldton greenstone belt forms the southern margin of the Wabigoon Subprovince. It is bounded on the south by the Quetico Subprovince and to the north by batholithic bodies within the Wabigoon (Figure 1). The geology of the belt has been extensively studied and comprehensively reviewed [13]. Based on the foregoing and more recent work [14], the geology will be summarized here.

As illustrated in Figure 1, the Beardmore-Geraldton greenstone belt is comprised of three successions of mafic metavolcanic rocks overlain by metasedimentary rocks. Both rock types have been metamorphosed to greenschist facies. They have been designated as the southern volcanic belt (SVB), southern metasedimentary belt (SMB), central volcanic belt (CVB), central metasedimentary belt (CMB), northern volcanic belt (NVB) and northern metasedimentary belt (NMB) [15]. The belts are continuous from Beardmore to Geraldton, striking east-west, except for the NVB, which is disrupted west of Geraldton. The metasedimentary rocks have been interpreted as representing a cratonic margin sequence shoaling northward [16-19], but together with the underlying volcanic rocks has been stacked in a series of three thrust slices $[20,21]$.

The NMB and the northern portions of the CMB and SMB are dominantly composed of conglomerate with minor amounts of sandstone. The SMB contains turbiditic units with oxide facies iron formation interbedded with sandstone and siltstone [13]. The metavolcanics have been variously interpreted as slices of sea-floor [20], as back arc volcanics [15] or as island arc tholeites [14], who provided detailed geochemistry of the rocks. 


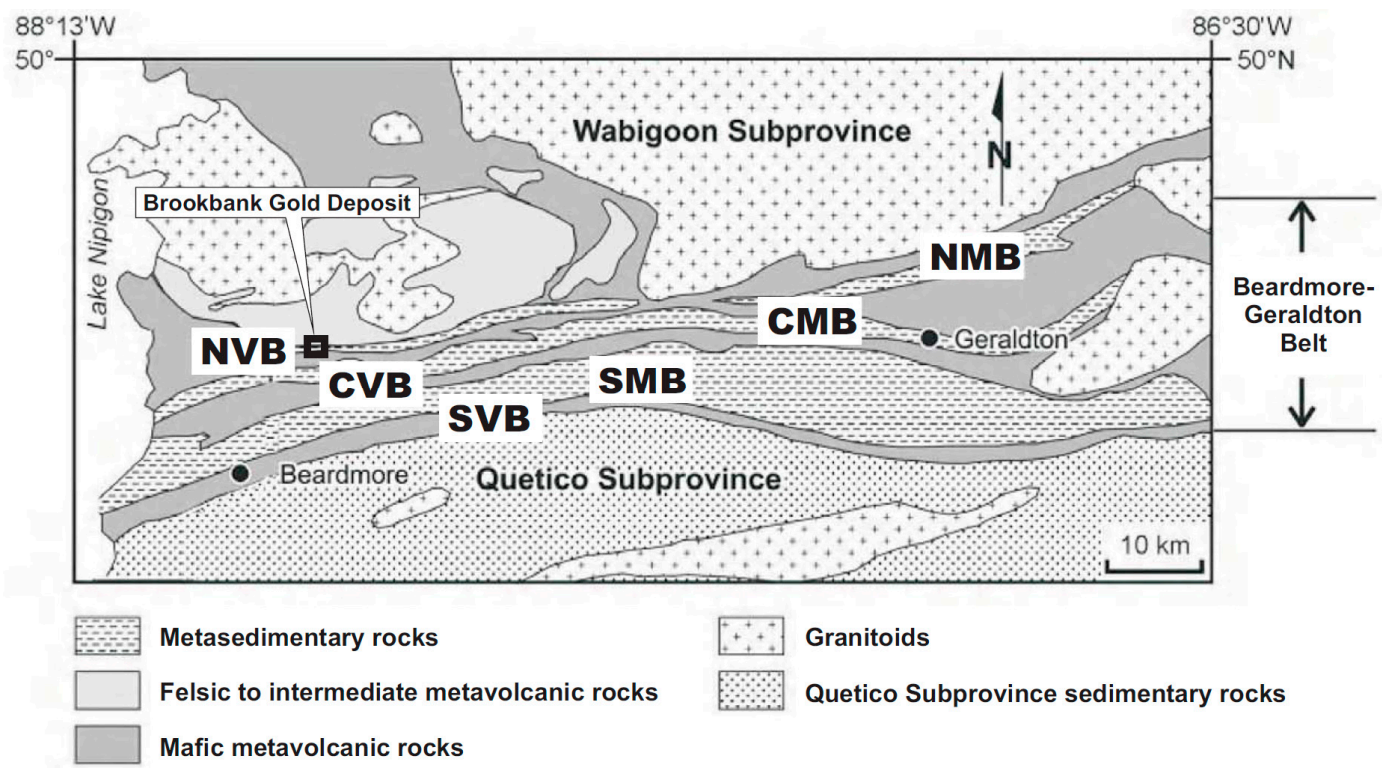

Figure 1. Geology of the Beardmore-Geraldton greenstone belt, with the location of the Brookbank gold deposit. $\mathrm{NVB}=$ northern volcanic belt; $\mathrm{NMB}=$ northern metasedimentary belt; $\mathrm{CVB}=$ central volcanic belt; $\mathrm{CMB}=$ central metasedimentary belt; $\mathrm{SMB}=$ southern metasedimentary belt; $\mathrm{SVB}=$ southern volcanic belt. Modified after [22]. Reproduced with permission from the Ontario Geological Survey, published by the Queen's Printer for Ontario.

The structural history of the Beardmore-Geraldton greenstone belt is complex and has been studied in detail [23]. Based on a detailed structural analysis, three periods of deformation were recognized. The first phase produced the thrust faulting resulting in the three metavolcanic-metasedimentary slices. The second phase steepened dips of the rocks to near vertical, and the third phase is interpreted as synchronous with peak metamorphic conditions accompanied by dextral shearing and formation of Z-folds, especially in the Geraldton area [14].

Gold deposits in the Beardmore-Geraldton greenstone belt were principally in the Beardmore and Geraldton areas [3]. In the Geraldton area gold deposits are hosted in banded iron formation, which is generally believed to have formed an impermeable trap for migrating gold-carrying solutions, as well as a chemically reactive material in the form of magnetite. In the Beardmore area, the deposits are hosted in turbiditic sandstones, which were cross-cut by quartz-carbonate veins. Summarizing, the Geraldton are deposits are iron-formation deposits, whereas the Beardmore area deposits are veins hosted in sandstone [14]. In both cases the regional Paint Lake deformation zone is believed to have been the path for gold-bearing solutions to enter splay faults where the deposits are located [13].

\subsection{Geology of the Brookbank Deposit}

The availability of drill core for this study provided a means of examination of the ores and alteration at depth, with particular emphasis on the nature of the ore-depositing solution by means of fluid inclusion analysis. A comprehensive study of surface samples treated the petrology of the host rocks, alteration, structure, geochemistry and ore mineralogy [14]. The Brookbank deposit occurs within a shear zone, the Brookbank shear zone, a splay of the Paint Lake deformation zone (Figure 2). The shear zone strikes N70W and dips steeply to the south, roughly parallel to bedding (Figure 3). The Cherbourg Zone lies $900 \mathrm{~m}$ to the west of the Brookbank along a splay from the shear zone. The shear hosting the Cherbourg Zone strikes N30E, also dipping steeply. Younging directions in the host rocks at Brookbank face north, indicating that bedding is overturned [20,21]. 


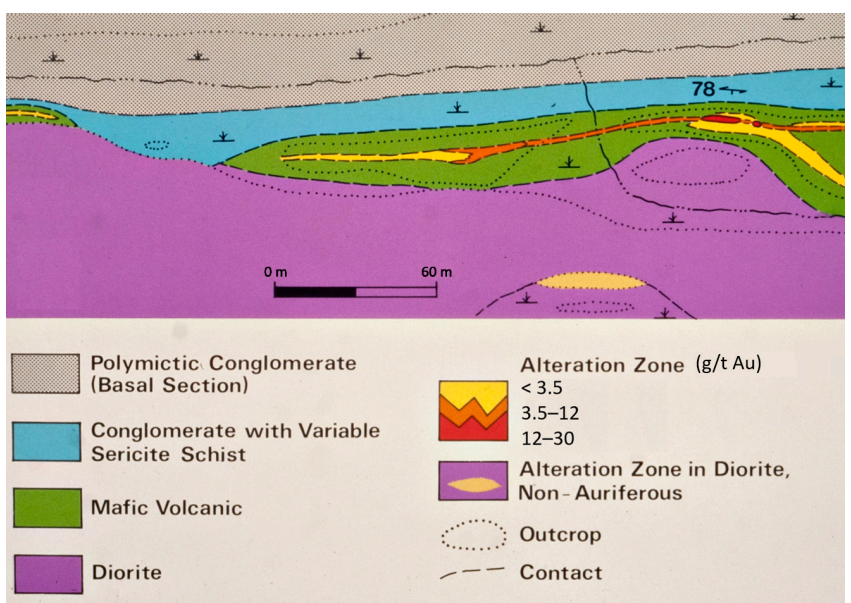

Figure 2. Surface geology of the Brookbank deposit.

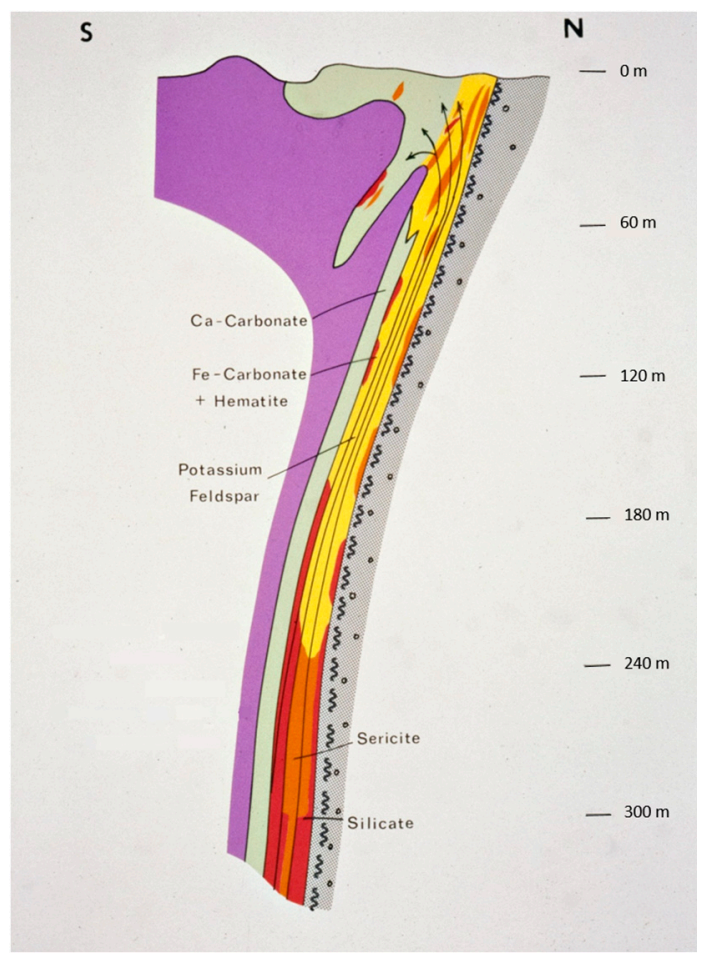

Figure 3. Schematic cross-section of the Brookbank deposits. Unit colors as in Figure 2.

The Brookbank deposit occurs within a shear zone contained mostly within pillowed and brecciated mafic volcanics. This unit overlies more massive, polymictic conglomerates containing variable amounts of sericite schist. The metavolcanics are intruded by a sill-like diorite body (Figure 3).

The Cherbourg zone is in a quartz-carbonate fissure vein, as opposed to a shear, along the contact between pillowed, mafic metavolcanics and a dioritic intrusion. The diorite body in both locations intrudes the metavolcanics and locally, the conglomerate. The diorite displays chilled contacts with the intruded rocks and is clearly a younger feature.

Veins within the Brookbank shear zone and the fissure vein in the Cherbourg zone were seen on the basis of cross-cutting relationships and characteristic alteration to have formed in three progressive stages: stage 1-pre-ore stage; stage 2-ore deposition stage; and stage 3-post-ore stage. The vein stages are enclosed within an alteration envelope that overprinted greenschist facies metamorphism of the host rocks. Stage 1 quartz-carbonate veins occur within hematite-ankerite-alkali feldspar-chamosite 
alteration aggregates and veinlets. They do not contain gold, so are considered to be pre-ore, as they are cross-cut by auriferous veins from stage 2 . Stage 2 veins contain grey quartz with gold frequently associated with pyrite. They are considered to represent ore deposition. Stage 3 veinlets cross-cut the auriferous stage 2 veins. The veins contain white to pink quartz-calcite crystals. The deposits are presumed to have formed from the same ore-depositing system.

The Brookbank shear zone is composed of brecciated, mafic metavolcanic rocks, which were first flooded by quartz, then extensively replaced by ankerite with quartz and seams of hematite and minor pyrite and gold. The alteration then progresses to calcite-quartz-clinochlore/chamosite. These assemblages are partially overprinted by potassium feldspar-quartz-hematite alteration. At depth a late sericite-rich alteration with leucoxene and hematite occurs in patches. Finally, replacement by fine-grained ankerite with quartz, pyrite and hematite affected the earlier alteration. Gold is associated with pyrite at this stage. Alteration together with vein formation is present to only a minor extent in the footwall conglomerate.

The alteration associated with the fissure vein in the Cherbourg zone differs from that present at Brookbank, although the host rocks are the same; i.e., altered, mafic metavolcanics. The altered wallrock contains zones of ankerite, sericite-magnetite and potassium feldspar-quartz-calcite. The fissure vein pinches and swells from 10 to $150 \mathrm{~cm}$ width cross-cutting altered and deformed metavolcanics of the NVB. It is mineralized with pyrite, sphene, ilmentite, chalcopyrite, molybdentie, argentite and magnetite with traces of native gold, silver and copper. Gold with lessor silver is associated with pyrite within vein quartz. Quartz occurs in bands with ankerite and minor pyrite. Sericite is present in veinlets parallel to the quartz-ankerite bands.

\section{Methods}

\subsection{Sampling and Preparation}

Polished sections were made from 224 samples from Brookbank and from 143 samples from the Cherbourg Zone. Brookbank samples were taken from sections of nine drill cores that that penetrated the alteration zone enclosing the gold-bearing areas at various depths to a maximum $766 \mathrm{~m}$ (Table 1). The Cherbourg Zone samples were taken from surface exposures of the vein system along a set of lines transecting the alteration zone and enclosed vein system.

Table 1. Drill cores sampled, with depth of section sampled.

\begin{tabular}{ccc}
\hline Drill Hole & Maximum Depth $(\mathbf{m})$ & Minimum Depth $(\mathbf{m})$ \\
\hline B49 & 189.1 & 154.5 \\
B56 & 226.2 & 203.3 \\
B58 & 265.8 & 241.4 \\
B53 & 303.9 & 271.3 \\
B43 & 323.7 & 306.9 \\
B50 & 417.3 & 399.0 \\
B54 & 512.1 & 497.4 \\
B61 & 586.1 & 581.3 \\
B46 & 768.0 & 743.7 \\
\hline
\end{tabular}

Doubly polished sections $150 \mu \mathrm{m}$ thick were prepared utilizing a cold setting adhesive resin to mount the material during polishing. A coolant was used during polishing in order to minimize frictional heating. At no stage during the preparation of the sections were they heated above $100{ }^{\circ} \mathrm{C}$.

\subsection{Analysis}

Fluid inclusions were examined using a United States Geological Survey type heating/freezing stage [24] mounted on a Leitz Orthoplan petrographic microscope. Heating was accomplished by flowing nitrogen gas through a glass tube containing a heating coil connected to the sample chamber. Freezing was accomplished by flowing nitrogen gas cooled by liquid nitrogen. Heating was carried 
out at a rate of $1{ }^{\circ} \mathrm{C} / \mathrm{min}$ and cooling at $1-2{ }^{\circ} \mathrm{C} / \mathrm{min}$. This method eliminated thermal gradients in the sample chamber, and, in any case, the thermocouple rests directly on the sample. Temperatures were measured by a Doric Series 400A Trendindicator digital thermometer. The thermocouple used in this study was calibrated over the temperature range -95.0 to $+302.0^{\circ} \mathrm{C}$ against 13 melting point standards. The maximum deviation from a standard temperature was $-2.2^{\circ} \mathrm{C}$, but the remaining measurements were mostly within $\pm 0.5^{\circ} \mathrm{C}$ of the calibration points, yielding a standard error of estimate $\pm 0.7^{\circ} \mathrm{C}$. These errors are of the same magnitude as random errors of measurement.

The host minerals of fluid inclusions were quartz, calcite and, in stage 2 clinochlore, as well. Details are provided in the Supplementary Tables S1-S10. Measurements were made on primary and pseudosecondary inclusions. Secondary inclusions were aligned along fractures and were filled with liquid $\mathrm{H}_{2} \mathrm{O}$; they were not further studied. Fluid inclusions from the Cherbourg Zone, selected on the basis of their relatively large size, were analyzed for their content of molecular species by means of laser Raman spectrography by J.D. Pasteris at Washington University, St. Louis, MO, USA.

\section{Results}

The complete results of analyses of 375 fluid inclusions from the Brookbank and Cherbourg Zone deposits are given in Supplementary Tables S1-S10. The results of the fluid inclusion analysis showed that the pre-ore and post-ore stages 1 and 3, respectively, yielded differing properties among groups of fluid inclusions. Hence, stage 1 has A, B and C subdivisions, and stage 3 has A and B subdivisions. The fluid inclusion data are summarized in Table 2, and Table 3 defines the inclusion types and abbreviations used in Table 2. A comparison of the homogenization temperatures in fluid inclusions from the two deposits is shown in Figure 4. Fluid inclusions were generally quite small ( 2 to $5 \mu \mathrm{m}$ diameter), making some observations difficult.

Table 2. Summary of fluid inclusion results.

\begin{tabular}{|c|c|c|}
\hline Stage & Brookbank & Cherbourg Zone \\
\hline Stage 1A & $\begin{array}{l}30 \text { inclusions: type } 1 \text { and } 3 \\
\text { Te: }-22.0 \text { to }-22.9 \\
\text { Tm ice: }-0.1 \text { to }-6.6 \\
\text { Th: } 220.1 \text { to } 235.3\end{array}$ & $\begin{array}{l}42 \text { inclusions: type } 1 \text { and } 3 \\
\text { Te: }-21.1 \text { to }-22.9 \\
\text { Tm ice: }-0.4 \text { to }-0.5 \\
\text { Th: } 220.3 \text { to } 231.1 \\
\text { Tm clath *: } 10.4 \text { to } 10.6\end{array}$ \\
\hline Stage 1B & $\begin{array}{l}15 \text { inclusions: type } 3 \\
\text { Te: }-52.1 \text { to }-52.8 \\
\text { Tm ice: }-0.3 \text { to }-0.8 \\
\text { Th: } 230.1 \text { to } 266.4\end{array}$ & $\begin{array}{l}35 \text { inclusions: type } 1 \text { and } 3 \\
\text { Te: }-50.1 \text { to }-53.4 \\
\text { Tm ice: }-0.4 \text { to }-0.5 \\
\text { Th: } 229.3 \text { to } 231.0\end{array}$ \\
\hline Stage $1 \mathrm{C}$ & $\begin{array}{l}57 \text { inclusions: type } 1 \text { and } 3 \\
\text { Te: }-55.0 \text { to }-55.9 \\
\text { Tm ice: }-0.3 \text { to }-0.8 \\
\text { Th: } 353.5 \text { to } 364.2\end{array}$ & Not observed \\
\hline Stage 2 & $\begin{array}{l}82 \text { inclusions: type } 4 \mathrm{~A} \text { and } 4 \mathrm{~B} \\
\text { Te: }-33.9 \text { to }-35.8 \\
\text { Tm ice: } 0.1 \text { to }-8.8 \\
\text { Th: } 258.3 \text { to } 269.1\end{array}$ & $\begin{array}{l}35 \text { inclusions: type } 4 \mathrm{~A} \text { and } 4 \mathrm{~B} \\
\text { Te: }-35.0 \text { to }-35.9 \\
\text { Tm ice: }-0.1 \\
\text { Th: } 265.8 \text { to } 267.1 \\
\text { Tm clath } * 10.5\end{array}$ \\
\hline Stage 3A & $\begin{array}{l}40 \text { inclusions: type } 3 \\
\text { Te: }-56.3 \\
\text { Tm ice: }-0.7 \text { to }-8.3 \\
\text { Th: } 32.3 \text { to } 32.9\end{array}$ & $\begin{array}{l}8 \text { inclusions: type } 3 \\
\text { Te: }-54.9 \text { to }-56.6 \\
\text { Tm ice: }-0.9 \\
\text { Th: } 32.0 \text { to } 55.9 \\
\text { Tm clath } * 10.4\end{array}$ \\
\hline Stage 3B & Not observed & $\begin{array}{l}23 \text { inclusions: type } 3 \\
\text { Te: }-14.1 \text { to }-15.9 \\
\text { Tm ice: }-1.1 \text { to }-1.2 \\
\text { Th: } 21.6 \text { to } 69.8\end{array}$ \\
\hline
\end{tabular}

* When observed. 
Table 3. Fluid inclusion terminology and types.

\begin{tabular}{c}
\hline Fluid Inclusion Terminology \\
\hline Te = eutectic temperature \\
Tm ice = melting temperature of ice \\
Tm clath = melting temperature of clathrate \\
$\mathrm{Th}=$ temperature of homogenization \\
\hline Types of Fluid Inclusions \\
(Phases present at room temperature) \\
\hline Type 1: $\mathrm{L}_{\mathrm{aq}}+\mathrm{V}$ \\
Type 2: $\mathrm{L}_{\mathrm{CO} 2}+\mathrm{V}_{\mathrm{CO} 2}$ \\
Type $3: \mathrm{L}_{\mathrm{aq}}+\mathrm{V}_{\mathrm{CO} 2}+\mathrm{H}_{2} \mathrm{O}$ \\
Type $4 \mathrm{~A}: \mathrm{L}_{\mathrm{aq}}+: \mathrm{L}_{\mathrm{CO} 2}+\mathrm{V}$ \\
Type $4 \mathrm{~B}: \mathrm{L}_{\mathrm{aq}}+: \mathrm{L}_{\mathrm{CO} 2}+\mathrm{V}+\mathrm{S}$ \\
\hline $\mathrm{L}_{\mathrm{aq}}=\mathrm{H}_{2} \mathrm{O}+$ dissolved chloride \\
$\mathrm{S}=$ unidentified unreactive solid \\
\hline
\end{tabular}

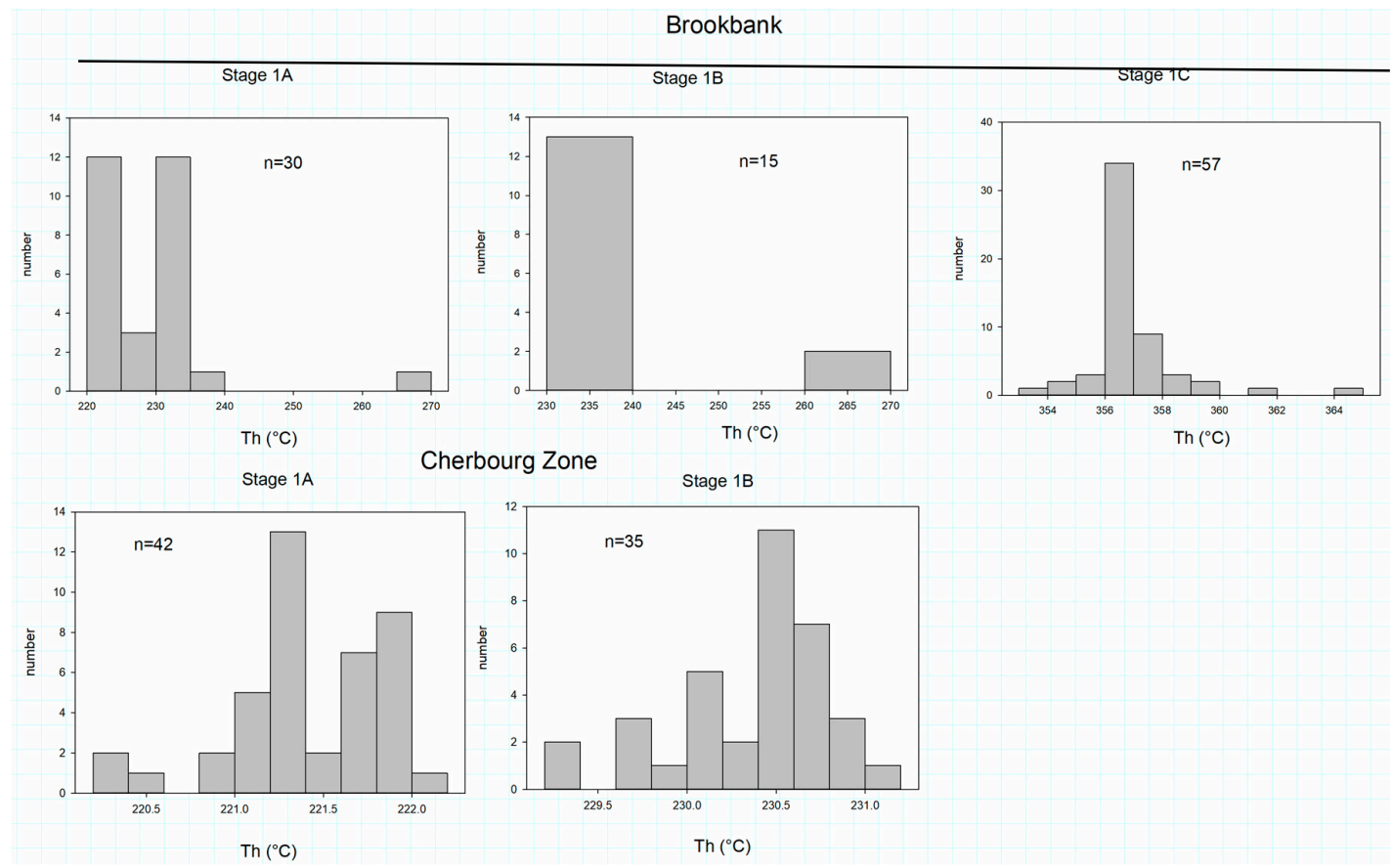

Figure 4. Cont. 
Brookbank
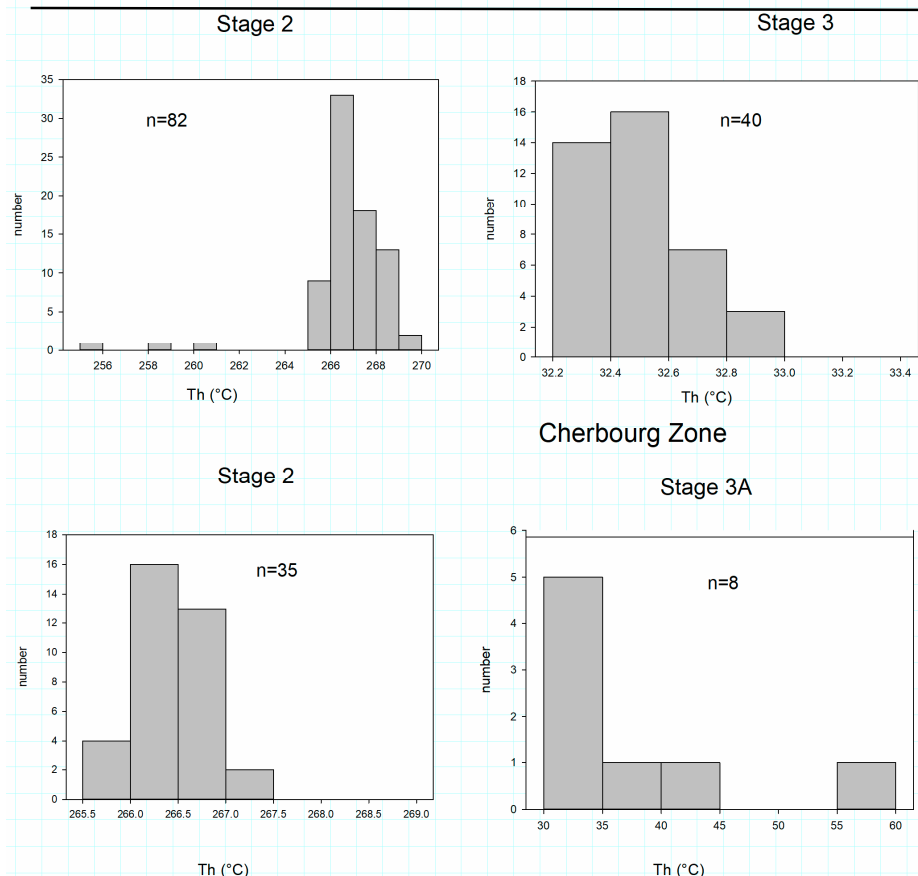

Cherbourg Zone
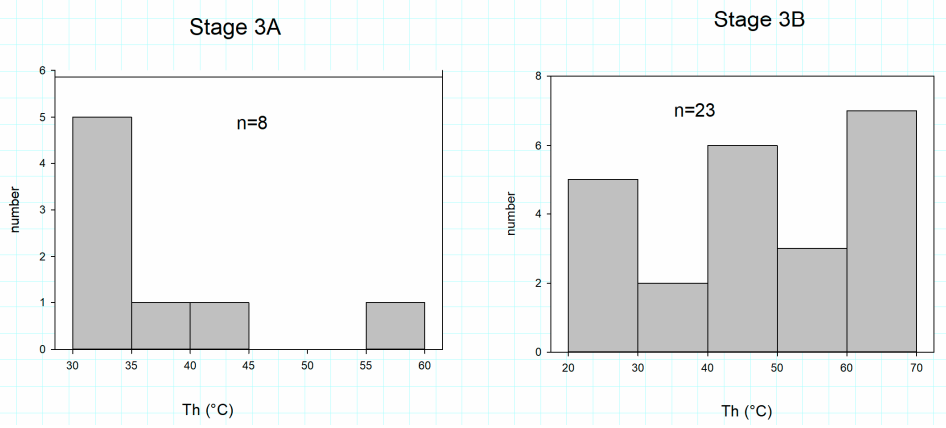

Figure 4. Comparative homogenization temperatures of the stages at Brookbank and the Cherbourg Zone.

\subsection{Stage $1 A$}

The data from Brookbank and the Cherbourg Zone fluid inclusions are quite similar in many respects with some significant differences. The eutectic temperatures (Te) reflecting first melting from both data sets span the range of $\mathrm{Te}$ for the $\mathrm{NaCl}-\mathrm{H}_{2} \mathrm{O}$ system at $-21.2{ }^{\circ} \mathrm{C}$ to that of the $\mathrm{NaCl}-\mathrm{KCl}-\mathrm{H}_{2} \mathrm{O}$ system at $-22.9^{\circ} \mathrm{C}$. In fact, the mean Te for the Cherbourg Zone is $-22.04{ }^{\circ} \mathrm{C} \pm 0.43($ S.E., $n=42)$, at the midpoint between the two eutectic temperatures, whereas the mean Te for Brookbank is $-22.40 \pm 0.29$ (S.E., $\mathrm{n}=29$ ). The latter is closer to the $\mathrm{NaCl}-\mathrm{KCl}-\mathrm{H}_{2} \mathrm{O}$ eutectic; however, it has been noted that at the accuracy of most measurements, the two eutectics cannot be reliably distinguished [25]. The freezing point depression, as determined by the final melting of ice ( $\mathrm{Tm}$ ice), is a function of salinity, but at the small depression measured here, the difference between the effect of $\mathrm{NaCl}-\mathrm{H}_{2} \mathrm{O}$ and $\mathrm{NaCl}-\mathrm{KCl}-\mathrm{H}_{2} \mathrm{O}$ is negligible, so the well-established relation between $\mathrm{Tm}$ ice and salinity in wt $\% \mathrm{NaCl}$ is employed [25].

The salinity for Cherbourg Zone fluid inclusions is therefore $0.7-0.9 \mathrm{wt} \% \mathrm{NaCl}$ equivalent, whereas the salinity of Brookbank fluid inclusions is variable and ranges as low as $0.2 \mathrm{wt} \% \mathrm{NaCl}$ equivalent to as high as $10.0 \mathrm{wt} \% \mathrm{NaCl}$ equivalent. This range to higher salinities results in different behavior on heating to homogenization from that observed in Cherbourg Zone fluid inclusions.

Homogenization temperature (Th) for both deposits are similar, but Brookbank exhibited a range of $15^{\circ} \mathrm{C}$ with no discernable relationship to depth of the drill core sample. (A single $\mathrm{Th}=266.8^{\circ} \mathrm{C}$ was determined, but possibly is an erroneous measurement). The difference between the two data sets is present in the homogenization phase; i.e., whether the liquid + vapor homogenized to liquid (L) or vapor $(\mathrm{V})$. The Cherbourg Zone fluid inclusions mostly homogenized to L (36 to L, 6 to V), whereas the opposite occurred in the Brookbank fluid inclusions (6 to L, 24 to V). The difference can be ascribed to the effects of the $\mathrm{CO}_{2}$ content and the salinity of the fluid inclusions. In the case of the Cherbourg Zone fluid inclusions, the effect of the low, consistent salinity would produce a path through a field of immiscibility ending with homogenization to $L$ in most cases. Some inclusions would homogenize to $\mathrm{V}$ if on heating they followed other isochors in $\mathrm{P}-\mathrm{T}$ space. The Brookbank fluid inclusions with some significantly higher salinities would strongly affect isochors in the $\mathrm{H}_{2} \mathrm{O}-\mathrm{CO}_{2}$ system, leading to homogenization to $\mathrm{V}$ [26]. 
The presence of $\mathrm{CO}_{2}$ in the Cherbourg Zone inclusions was obvious from the presence of in clathrates in most cases and its inferred presence in the remainder. Clathrates were not seen in the Brookbank inclusions, but the effect of salinity may have made them difficult to observe. However, the behavior of the fluid inclusions strongly suggests their presence. The invariant point for clathrate melting in the $\mathrm{H}_{2} \mathrm{O}-\mathrm{CO}_{2}$ system is $+9.8^{\circ} \mathrm{C}$ [26], so the observed measurements of +10.4 and $10.5^{\circ} \mathrm{C}$ are within the standard error of estimate.

The source of the fluids forming the quartz-calcite veins at this stage may be from dehydration reactions during the greenschist facies metamorphism of the host rocks. However, particularly with the variable salinity of the Brookbank inclusions, there may have been a contribution from ancient saline waters in the host rocks, as has been documented elsewhere [27].

\subsection{Stage $1 B$}

Fluid inclusions from both deposits yielded eutectic temperatures within $1{ }^{\circ} \mathrm{C}$ of the eutectic for the system $\mathrm{NaCl}-\mathrm{CaCl}_{2}-\mathrm{H}_{2} \mathrm{O}$ at $-52{ }^{\circ} \mathrm{C}$. This system is characteristic of a number of geological environments, here most likely moderate grade metamorphic fluids [25]. As noted above, ancient saline waters may have been incorporated into the vein-forming fluid. Salinities as determined by melting point depression were low, -0.3 to $-0.8^{\circ} \mathrm{C}$ at Brookbank and -0.4 to $-0.5^{\circ} \mathrm{C}$ at the Cherbourg Zone.

At Brookbank, homogenization temperatures were mostly in the range of ca. $230-238{ }^{\circ} \mathrm{C}$, but temperatures rose $30{ }^{\circ} \mathrm{C}$ from the shallowest to the deepest drill core samples. All inclusions homogenized to $\mathrm{V}$ reflecting the effect of $\mathrm{CO}_{2}$ in the inclusions. Homogenization temperatures in the Cherbourg Zone samples were all close to $230^{\circ} \mathrm{C}$, but here was some variation in the homogenization phase, apparently related to the position of isochors in the $\mathrm{CO}_{2}$-containing system.

\subsection{Stage $1 C$}

Veins formed at this stage were identified only in Brookbank samples. The eutectic temperatures were all found to be within $1{ }^{\circ} \mathrm{C}$ of the eutectic for $\mathrm{CO}_{2}-\mathrm{H}_{2} \mathrm{O}$, although all were above that temperature of $-56{ }^{\circ} \mathrm{C}$ [26]. Melting point depressions were low but variable, and an electrolyte component in the $\mathrm{L}$ did not appear as a separate eutectic. It is possible that the closeness of the $\mathrm{CO}_{2}-\mathrm{H}_{2} \mathrm{O}$ eutectic at $-56{ }^{\circ} \mathrm{C}$ and the $\mathrm{NaCl}-\mathrm{CaCl}_{2}-\mathrm{H}_{2} \mathrm{O}$ eutectic at $-52{ }^{\circ} \mathrm{C}$ obscured the individual eutectics.

The fluid inclusions in this stage nearly all homogenized to $\mathrm{V}$ at much higher temperatures than in stage $1 \mathrm{~A}$ and $1 \mathrm{~B}$ veins. The source of the fluid trapped in these inclusions is unknown, but it has been noted that a similar high temperature episode occurred in the Geraldton area deposits [13]. That this stage of veins was not found at the Cherbourg Zone may be a function of the depth at which sampling was carried out at Brookbank as opposed to the surface samples from the Cherbourg Zone, or simply that the fault at the Cherbourg Zone was not joined to the Brookbank fault during this episode.

\subsection{Stage 2}

Ore stage fluid inclusions form Brookbank yielded eutectic temperatures within $1^{\circ} \mathrm{C}$ of the $\mathrm{MgCl}_{2}-\mathrm{NaCl}-\mathrm{H}_{2} \mathrm{O}$ eutectic at $-35^{\circ} \mathrm{C}$ [25]. Whereas the temperatures measured are consistent with this eutectic, additional possibilities are the $\mathrm{FeCl}_{2}-\mathrm{H}_{2} \mathrm{O}$ at $-35.0^{\circ} \mathrm{C}[28]$ and the $\mathrm{FeCl}_{3}-\mathrm{H}_{2} \mathrm{O}$ eutectic at $-37.0{ }^{\circ} \mathrm{C}$ with the hydrate $\mathrm{FeCl}_{3} \cdot 10 \mathrm{H}_{2} \mathrm{O}[28,29]$. The $\mathrm{Mg}$ component of the ore-depositing fluid may be related to formation of clinochlore alteration associated with ore deposition. On the other hand, the iron-containing systems are consistent with the abundant pyrite in the deposit. Without information on the composition of the liquid phase in the inclusions, it is not possible to distinguish among these alternatives or even a combination of them yielding a multicomponent system. All fluid inclusions but two homogenized in the temperature range of $266-269{ }^{\circ} \mathrm{C}$; the exceptions were 256 and $258^{\circ} \mathrm{C}$. However, there was no relationship between homogenization temperature and depth of the drill core sample. The homogenization phase was predominantly to $\mathrm{V}$ (55) with 27 to L. Freezing point depressions were all less than $1^{\circ} \mathrm{C}$ with the exception of eight inclusions whose freezing point depressions were in the range of $7-9^{\circ} \mathrm{C}$. 
Although the presence of fluid inclusions that homogenized to $\mathrm{L}$ or $\mathrm{V}$ was accepted as evidence of immiscibility, definitive proof was seen in two sets of inclusions from the same section (Table 4). In both cases the inclusions homogenized at the same temperature within the error of measurement. Table 4 also shows two sets of inclusions from cross-cutting veins in the same section, demonstrating that there was no difference in the fluid trapped in veins formed at different times.

Table 4. Relative ages of cross-cutting veins.

\begin{tabular}{|c|c|c|c|c|c|}
\hline Sample No. & $\mathrm{Th}^{\circ} \mathrm{C}$ & Homog. Phase & Tm Ice ${ }^{\circ} \mathrm{C}$ & Relative Age & Stage * \\
\hline \multirow{2}{*}{ BSK-B43-1043 } & 266.5 & $\mathrm{~L}$ & -0.5 & older & 2 \\
\hline & 32.5 & $\mathrm{~L}$ & -0.9 & younger & $3 \mathrm{~A}$ \\
\hline \multirow{4}{*}{ BSK-B46-2447 } & 266.9 & $\mathrm{~L}$ & -0.4 & oldest & 2 \\
\hline & 266.2 & $\mathrm{~L}$ & -0.4 & younger & 2 \\
\hline & 32.3 & $\mathrm{~V}$ & -0.9 & younger & $3 \mathrm{~A}$ \\
\hline & 32.5 & $\mathrm{~L}$ & -0.9 & youngest & $3 \mathrm{~A}$ \\
\hline \multirow{4}{*}{ BSK-B46-2472 } & 266.1 & $\mathrm{~L}$ & -0.5 & oldest & 2 \\
\hline & 267.3 & $\mathrm{~V}$ & -0.9 & younger & 2 \\
\hline & 32.9 & $\mathrm{~V}$ & -0.9 & younger & $3 \mathrm{~A}$ \\
\hline & 32.6 & V & -0.7 & youngest & $3 \mathrm{~A}$ \\
\hline \multirow{3}{*}{ BSK-B58-826 } & 268.2 & $\mathrm{~V}$ & -0.5 & oldest & 2 \\
\hline & 266.4 & $\mathrm{~V}$ & -0.4 & younger & 2 \\
\hline & 32.9 & $\mathrm{~V}$ & -4.3 & youngest & $3 \mathrm{~A}$ \\
\hline \multirow{2}{*}{ BSK-B50-950 } & 356.4 & $\mathrm{~V}$ & -0.4 & older & $1 \mathrm{C}$ \\
\hline & 32.6 & $\mathrm{~V}$ & -1.4 & younger & $3 \mathrm{~A}$ \\
\hline
\end{tabular}

Fluid inclusions from the Cherbourg Zone except for one inclusion yielded eutectic temperatures within $1{ }^{\circ} \mathrm{C}$ of at $-35^{\circ} \mathrm{C}$. Homogenization temperatures were all in the range 266 to $267^{\circ} \mathrm{C}$. While these properties are nearly identical to those in Brookbank inclusions, there was a marked difference in the homogenization phases. Here, 31 homogenized to $\mathrm{L}$ and 4 to $\mathrm{V}$, the opposite of what was seen at Brookbank. All the freezing point depressions but four were $0.1^{\circ} \mathrm{C}$, the four exceptions only slightly greater. Although liquid $\mathrm{CO}_{2}$ was seen in half the inclusions and inferred to be present in the remainder, clathrate melting was observed in only two inclusions. The melting temperature of $+9.8{ }^{\circ} \mathrm{C}$, is that of the $\mathrm{H}_{2} \mathrm{O}-\mathrm{CO}_{2}$ system, consistent with the low salinity indicated by the freezing point depression.

\subsection{Stage $3 A$}

At Brookbank, all fluid inclusions yielded a eutectic temperature within $1{ }^{\circ} \mathrm{C}$ of the $\mathrm{CO}_{2}-\mathrm{H}_{2} \mathrm{O}$ eutectic at $-56^{\circ} \mathrm{C}$. As well, all were type 3 inclusions with $\mathrm{CO}_{2}$ liquid present at room temperature. Of 40 fluid inclusions, all but six homogenized to V. Three of the six that homogenized to L had the largest freezing point depressions, from 6.8 to $8.3^{\circ} \mathrm{C}$. Freezing point depression in the remaining inclusions ranged widely from 4.3 to $0.7^{\circ} \mathrm{C}$, reflecting some variation in concentration of a salt in the vein-forming solution. However, a eutectic for the salt system was not detected in these fluid inclusions, perhaps owing to the high $\mathrm{CO}_{2}$-content. Homogenization temperatures were all within $1{ }^{\circ} \mathrm{C}$ of $32{ }^{\circ} \mathrm{C}$, reflecting the low temperature origin of the host veins.

Fluid inclusions from the Cherbourg Zone similarly yielded eutectic temperatures within $1{ }^{\circ} \mathrm{C}$ of the $\mathrm{CO}_{2}-\mathrm{H}_{2} \mathrm{O}$ eutectic at $-56{ }^{\circ} \mathrm{C}$. All inclusions were of type 3 ; however, clathrate melting at $+10.4{ }^{\circ} \mathrm{C}$ was detected in only one inclusion. Two of eight inclusions homogenized to $\mathrm{V}$, the opposite of the effect seen at Brookbank. Final melting of ice was at $-0.9^{\circ} \mathrm{C}$, indicating some saline content, but a pertinent eutectic was not observed.

\subsection{Stage $3 B$}

This stage was not observed at Brookbank and apparently represents introduction of a fluid at slightly higher temperature and saline content than in stage 3A.The fluid inclusions homogenized 
mostly to L over a range of temperatures from 21 to $70{ }^{\circ} \mathrm{C}$; however, the freezing point depressions measured were all 1.1 to $1.2^{\circ} \mathrm{C}$. All inclusion are of type 3 , but clathrate formation was not detected. Most interesting are the measured eutectic temperatures of -14.1 to $-18.6^{\circ} \mathrm{C}$, too high for $\mathrm{NaCl}_{-} \mathrm{H}_{2} \mathrm{O}$, and too low for $\mathrm{KCl}-\mathrm{H}_{2} \mathrm{O}$ at $-10.7^{\circ} \mathrm{C}$ [25]. A possible explanation, as has been suggested in $\mathrm{NaCl}-$ and $\mathrm{CaCl}_{2}$-bearing inclusions is the formation of metastable hydrates of $\mathrm{KCl}$ [18]. Metastable behavior in the $\mathrm{KCl}-\mathrm{H}_{2} \mathrm{O}$ system has been observed, possibly due to the presence of hydrates [30]. The existence of hydrates of the form $\mathrm{KCl} \cdot \mathrm{H}_{2} \mathrm{O}$ and $\mathrm{KCl} \cdot \mathrm{nH}_{2} \mathrm{O}$ have been reported in Russian literature [31].

\subsection{Raman Spectroscopy Results}

The results from seven fluid inclusions from the three stages of vein formation in sample BSK-C-0+95E-2 from the Cherbourg Zone are presented in Table 5. Fluid inclusions 1 and 2 from stage $1 \mathrm{~A}$ contain $\mathrm{CO}_{2}$, as anticipated from the presence of clathrates in these inclusions. Fluid inclusions 3-5 from stage 2 contain only $\mathrm{H}_{2} \mathrm{O}$, and in the case of inclusion $5, \mathrm{~N}_{2}$ as well was present. The failure to find $\mathrm{CO}_{2}$ in inclusions 5-7 may be due to a relatively low $\mathrm{CO}_{2}$-content in the inclusions of type 4A. Finally, inclusions 6 and 7 from stage $3 \mathrm{~B}$ contained both $\mathrm{CO}_{2}$ and $\mathrm{N}_{2}$. The source of $\mathrm{N}_{2}$ in the inclusions is uncertain, but at least in the case of inclusions 6 and 7 meteoric water is a possibility.

Table 5. Raman spectra results from Cherbourg Zone sample BSK-C-0+95E-2.

\begin{tabular}{ccccccccc}
\hline $\begin{array}{c}\text { Inclusion } \\
\text { No. }\end{array}$ & $\begin{array}{c}\text { Inclusion } \\
\text { Type }\end{array}$ & Stage & Te & Tm Ice & Th & $\begin{array}{c}\text { Homog } \\
\text { Phase }\end{array}$ & Tm Clath & $\begin{array}{c}\text { Phases } \\
\text { Detected }\end{array}$ \\
\hline 1 & 3 & 1 & -21.8 & -0.4 & 221.4 & $\mathrm{~L}$ & 10.5 & $\mathrm{CO}_{2}$ \\
2 & 3 & 1 & -21.8 & -0.4 & 221.4 & $\mathrm{~L}$ & 10.5 & $\mathrm{CO}_{2}$ \\
3 & $4 \mathrm{~A}$ & 2 & -35.3 & -0.1 & 266.2 & $\mathrm{~V}$ & - & $\mathrm{H}_{2} \mathrm{O}$ \\
4 & $4 \mathrm{~A}$ & 2 & -35.3 & -0.1 & 266.1 & $\mathrm{~V}$ & - & $\mathrm{H}_{2} \mathrm{O}$ \\
5 & $4 \mathrm{~A}$ & 2 & -35.2 & -0.1 & 266.3 & $\mathrm{~V}$ & - & $\mathrm{H}_{2} \mathrm{O}_{2} \mathrm{~N}_{2}$ \\
6 & 3 & 3 & -15.9 & -1.1 & 66.6 & $\mathrm{~L}$ & - & $\mathrm{CO}_{2}, \mathrm{~N}_{2}$ \\
7 & 3 & 3 & -15.9 & -1.1 & 66.3 & $\mathrm{~L}$ & - & $\mathrm{CO}_{2}, \mathrm{~N}_{2}$ \\
\hline
\end{tabular}

\section{Discussion}

The salinity and presence of $\mathrm{CO}_{2}$ in all stages of vein formation at Brookbank and the Cherbourg Zone is typical of lode gold deposits, especially in Archean terrains, e.g., [32]. The low salinity leads to a general low content of base metals carried as chloride complexes, whereas gold is soluble as bisulfide complexes, as demonstrated by many experimental studies [33-36], which are less effective as mobilizers of base metals [37]. The low abundance of base metal sulfides at these two deposits is thus consistent with transport of gold as a bisulfide complex.

The precipitation of gold from bisulfide complexes by various means has been proposed. Cooling will produce precipitation if the solution passes into the $\mathrm{SO}_{4}{ }^{2-}$ stability field from the $\mathrm{H}_{2} \mathrm{~S}$ stability field [38]. However, the temperature in stage 2 inclusions is nearly constant with depth in the drill core from Brookbank. This observation is consistent with the telescoped zoning of alteration, as has been observed in other deposits [39,40]. Mixing solutions, particularly low temperature, oxidized meteoric water, will lead to precipitation of gold by dilution of the complexing ligand as well as the factors mentioned above [39]. However, other than minor mixing of saline fluids, as seen by increases in freezing point depressions in a few cases, no evidence of fluid mixing was observed.

The eutectic temperature in stage 2 inclusions, as noted previously, corresponds to that of the $\mathrm{MgCl}_{2}-\mathrm{NaCl}-\mathrm{H}_{2} \mathrm{O}$ system. Although consistent with chlorite alteration, it does not provide an explanation for late potassium alteration producing potassium feldspar. The presence of potassium feldspar-quartz-pyrite alteration has been attributed introduction of a high temperature $\left(500-700{ }^{\circ} \mathrm{C}\right)$ fluid possibly of magmatic origin [14]. However, there is no evidence of such high temperature potassium-bearing inclusions.

The possible introduction of potassium may be seen in stage 3B inclusions, which may have trapped KCl-bearing fluids at low temperatures. The patchy presence of potassium feldspar alteration 
is suggestive of regional potassium alteration, which is widespread in the Canadian Shield [41,42]. Replacement of plagioclase by potassium feldspar is the typical result of this process [43].

The phenomenon observed in stage 2, immiscibility producing phase separation such that coexisting fluid inclusions homogenized to $\mathrm{L}$ and $\mathrm{V}$. Volatile species such as $\mathrm{CO}_{2}$ and $\mathrm{H}_{2} \mathrm{~S}$ would preferentially partition to the $\mathrm{V}$ phase. Figure 5 illustrates the $\mathrm{CO}_{2}-\mathrm{H}_{2} \mathrm{O}$ system as a function of pressure vs. mole fraction $\mathrm{CO}_{2}$ (lower abscissa) and volume percent $\mathrm{CO}_{2}$ (upper abscissa) with isotherms of coexisting phases for selected temperatures. The homogenization temperatures for Brookbank and Cherbourg Zone fluid inclusions are plotted based on the homogenization phases to $\mathrm{V}$ and $\mathrm{L}$, respectively. It is recognized that salinity has the effect of raising the critical temperature and solvus of the $\mathrm{CO}_{2}-\mathrm{H}_{2} \mathrm{O}$ system. However, decreasing pressure in the $\mathrm{CO}_{2}-\mathrm{H}_{2} \mathrm{O}-\mathrm{NaCl}$ system operates so as to lower the critical point and solvus. Salinity in equivalent wt $\% \mathrm{NaCl}$ for the Cherbourg Zone is $0.2 \mathrm{wt} \%$ based on freezing point depression $0.1{ }^{\circ} \mathrm{C}$ [25]. This not likely to raise the critical point more than $10^{\circ} \mathrm{C}$, based on comparison with the effect of higher salinities [44]. The mean freezing point depression for Brookbank inclusions, excluding some aberrantly high values, is $0.36{ }^{\circ} \mathrm{C}$, corresponding to $0.6 \mathrm{wt} \% \mathrm{NaCl}$ equivalent [25]. At $100 \mathrm{Mpa}$, the peak of the solvus is raised by approximately $55^{\circ} \mathrm{C}$ in a $2.6 \mathrm{wt} \% \mathrm{NaCl}$ fluid [45].Thus, $0.36 \mathrm{wt} \% \mathrm{NaCl}$ can be anticipated to have a smaller effect, perhaps 10 to $15^{\circ} \mathrm{C}$. Note that this comparison of salinities does not account for the effect of the contribution of $\mathrm{CO}_{2}$ to freezing point depression; however, the effect is small and comparable at these low calculated salinities [46].

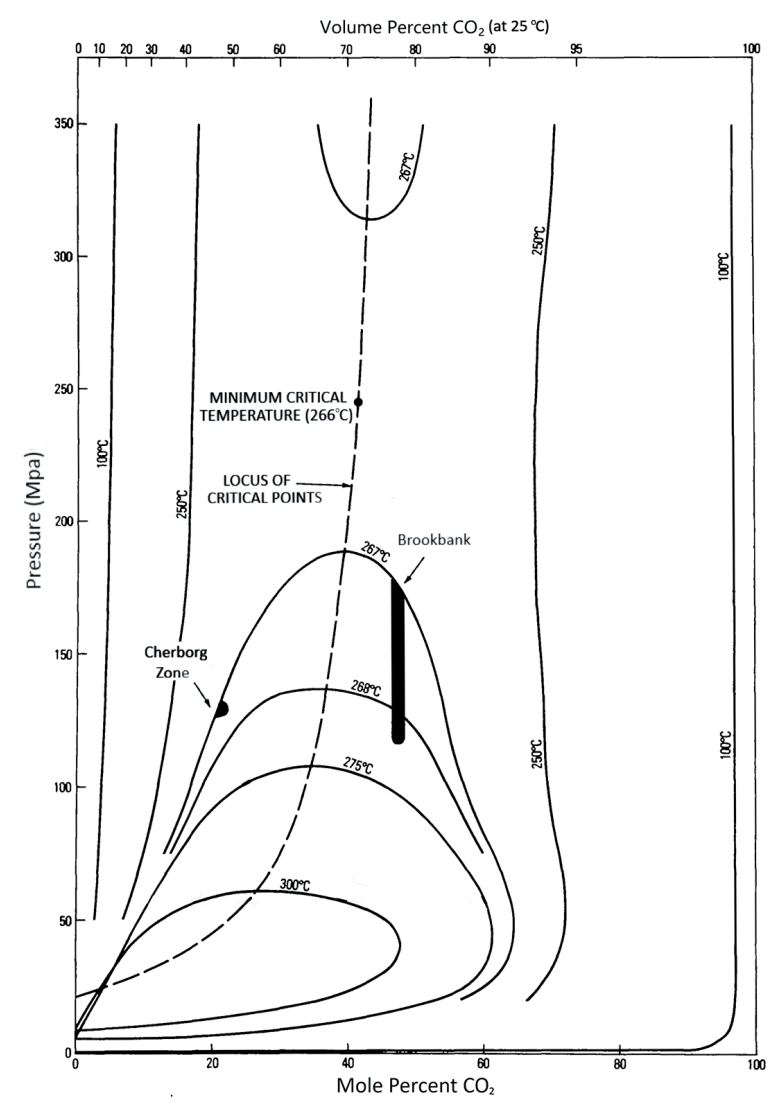

Figure 5. The $\mathrm{CO}_{2}-\mathrm{H}_{2} \mathrm{O}$ system with the approximate position of inclusions homogenized to vapor for Brookbank and homogenized to liquid for the Cherbourg Zone. The values of mole percent $\mathrm{CO}_{2}$ are schematic based only on the homogenization temperatures of fluid inclusions. The effect of salinity is discussed in the text. Modified after [47]. Reproduced with permission from the Annual Reviews of Earth and Planetary Science; published by Annual Reviews. 
The L-rich phase at the Cherbourg Zone would have precipitated gold owing to instability of the complex $\mathrm{Au}(\mathrm{HS})_{2}{ }^{-}$with the loss of $\mathrm{H}_{2} \mathrm{~S}$ to the $\mathrm{V}$-phase. As well, accompanying the influx of quartz as temperature declined, pyrite and calcite would form by reaction with alteration ankerite with the remaining $\mathrm{H}_{2} \mathrm{~S}$ in solution:

$$
\mathrm{CaFe}\left(\mathrm{CO}_{3}\right)_{2}+2 \mathrm{H}_{2} \mathrm{~S}+1 / 2 \mathrm{O}_{2}=\mathrm{CaCO}_{3}+\mathrm{FeS}_{2}+\mathrm{CO}_{2}+2 \mathrm{H}_{2} \mathrm{O}
$$

Gold would have tended to be associated with pyrite by a reaction (unbalanced) such as [48]:

$$
\mathrm{CaFe}\left(\mathrm{CO}_{3}\right)_{2}+\mathrm{Au}(\mathrm{HS})_{2}{ }^{-}=\mathrm{CaCO}_{3}+\mathrm{FeS}_{2}+\mathrm{Au}+\mathrm{CO}_{2}+\mathrm{H}_{2} \mathrm{O}
$$

Thus, the association of ankeritic alteration with the ore-depositing stage, as well as with pyrite and calcite in the veins is explained.

Experimental work has established that gold can be transported in a $\mathrm{H}_{2} \mathrm{~S}-\mathrm{H}_{2} \mathrm{O}$ gas phase as $\mathrm{AuS}\left(\mathrm{H}_{2} \mathrm{~S}\right)_{n}$ complexes $[49,50]$. This would permit concentrations of gold to be deposited at Brookbank by means of the same mechanisms as those in effect at the Cherbourg Zone. Calculation of the phase diagram for the system is possible in principle by the use of equations of state, e.g., [51]. However, the lack of data for the mole fraction of $\mathrm{CO}_{2}$ in this study, owing to the small size of inclusions, does not allow for this possibility.

Based on the approximations made in Figure 5, the pressure at trapping of inclusions at the Cherbourg Zone would be on the order of $130 \mathrm{Mpa}$. For Brookbank, the range of homogenization pressures at trapping of inclusion would range from 120 to $170 \mathrm{Mpa}$. The change in pressure may correspond to the change in style of mineralization, shear zone at Brookbank and fissure vein at the Cherbourg Zone. Most noteworthy is that this change occurred at the onset of immiscibility in the system. As has been noted [14], Brookbank is the only deposit in the NVB. Moreover, it contrasts with fissure deposits typical of the Beardmore area. These fluid inclusion studies provide an explanation for the development of shear zone vs. fissure vein deposits. These contrasting styles of mineralization can also be considered to represent a transition from mesothermal to epithermal conditions in lode gold deposits.

Supplementary Materials: The following are available online at www.mdpi.com/2015-163x/8/3/92/s1, Table S1: Fluid inclusion data-Brookbank Stage 1A, Table S2: Fluid inclusion data-Cherbourg Zone Stage 1A, Table S3: Fluid inclusion data-Brookbank Stage 1B, Table S4: Fluid inclusion data-Cherbourg Zone Stage 1B, Table S5. Fluid inclusion data-Brookbank Stage 1C, Table S6: Fluid inclusion data-Brookbank Stage 2, Table S7: Fluid inclusion data-Cherbourg Zone Stage 2, Table S8: Fluid inclusion data-Brookbank Stage 3A, Table S9: Fluid inclusion data: Cherbourg Zone Stage 3A, Table S10: Fluid inclusion data: Cherbourg Zone Stage 3B.

Acknowledgments: The former Metalore Resources Ltd. is thanked for support of B.S.K. and for access to the property and drill core. We are grateful to Jill Pasteris for the Raman spectrographic analyses of selected fluid inclusions. Anne Hammond prepared the many polished sections for the fluid inclusion work.

Author Contributions: The late Barbara Kowalski selected the study area and collected and sampled the study material. The analytical method was assigned and supervised by Stephen Kissin. Data were collected and organized by Barbara Kowalski. Data analysis was done by Barbara Kowalski and Stephen Kissin. The paper was written by Stephen Kissin.

Conflicts of Interest: The authors declare no conflict of interest. The founding sponsors had no role in the design of the study; in the collection, analyses, or interpretation of data.

\section{References}

1. Greenstone Gold Mines. Development of the Trans-Canada Property. Available online: http://www. greenstonegoldmines.com/ (accessed on 16 August 2017).

2. Blackburn, C.W.; Johns, G.W.; Ayer, J.A.; Davis, D.W. Wabigoon Subprovince. In Geology of Ontario; Thurston, P.C., Williams, H.R., Sutcliffe, R.H., Stott, G.M., Eds.; Ontario Geological Survey: Sudbury, ON, Canada, 1991; Special Volume 4, Part 1; pp. 303-381, ISBN 13: 9780772989761. 
3. Mason, J.K.; McConnell, C.D. Gold mineralization in the Beardmore-Geraldton area. In The Geology of Gold in Ontario; Colvine, A.C., Ed.; Ontario Geological Survey Miscellaneous Paper; Ontario Geological Survey: Sudbury, ON, Canada, 1983; pp. 84-97.

4. Lewis, W.J.; Murahwi, C.Z.; San Martin, A.J. Technical Report on the Mineral Resource Estimates for the Hardrock, Brookbank and Keylake Projects Trans-Canada Property, Beardmore-Geraldton Area Northern Ontario. 2013. Available online: www.premiergoldmines.com/assets/docs/Trans-Canada-Version-FinalJan-2013-(LQ).pdf (accessed on 4 July 2017).

5. Ontex Resources Drilling Campaign Aimed to Enhance Open Pit Potential of 629,900 Oz Brookbank Gold Deposit. 2009. Available online: http://www.marketwired.com/press-release/ontex-resources-drillingcampaign-aimed-enhance-open-pit-potential-629900-oz-brookbank-tsx-ont-793645.htm (accessed on 11 November 2017).

6. McCuaig, T.C.; Kerrich, R. P-T-t-deformation-fluid characteristics of lode gold deposits: Evidence from alteration systematics. Ore Geol. Rev. 1998, 12, 381-453. [CrossRef]

7. Lindgren, W. Mineral Deposits, 4th ed.; McGraw-Hill: New York, NY, USA, 1933.

8. Sibson, R.H.; Robert, F.; Poulsen, K.H. High-angle reverse faults, fluid-pressure cycling, and mesothermal gold-quartz deposits. Geology 1988, 16, 551-555. [CrossRef]

9. Robb, L. Introduction to Ore-Forming Processes; Blackwell Publishing: Malden, MA, USA, 2005; ISBN 0-632-06378-5.

10. Sibson, R.H. Earthquake rupturing as a mineralizing agent in hydrothermal systems. Geology 1987, 15, 701-704. [CrossRef]

11. Robert, F.; Poulsen, K.H. Vein formation and deformation in greenstone gold deposits. In Structural Controls on Ore Genesis; Richards, J.P., Tosdal, R.M., Eds.; Reviews in Economic Geology; Society of Economic Geologists: Littleton, CO, USA, 2001; Volume 14, pp. 111-115, ISBN 1-887483-58-6.

12. Kowalski, B.S. Petrographic and Fluid Inclusion Studies on the Metalore-Golden Highway Deposit, Thunder Bay District, Ontario. M.Sc. Thesis, Lakehead University, Thunder Bay, ON, Canada, 1994.

13. Smyk, M.C.; Fralick, P.; Hart, T.R. Geology and gold mineralization of the Beardmore-Geraldton greenstone belt. In 51st Annual Meeting, Proceedings of Institute on Lake Superior Geology, Nipigon, ON, Canada, 24-28 May 2005; Hollings, P., Ed.; 51st Institute on Lake Superior Geology: Nipigon, ON, Canada, 2005; Volume 51, part 2; pp. 3-40.

14. DeWolfe, J.C.; Lafrance, B.; Stott, G.M. Geology of the shear-hosted Brookbank gold prospect in the Beardmore-Geraldton belt, Wabigoon subprovince, Ontario. Can. J. Earth Sci. 2007, 44, 925-946. [CrossRef]

15. Tomlinson, K.Y.; Hall, R.P.; Hughes, D.J.; Thurston, P.C. Geochemistry and assemblage accretion of metavolcanic rocks in the Beardmore-Geralton greenstone belt, Superior Province. Can. J. Earth Sci. 1996, 33, 1520-1533. [CrossRef]

16. Devaney, J.R.; Fralick, P.W. Regional sedimentology of the Namewaminikan Group, northern Ontario: Archean fluvial fans, braided rivers, deltas and an aquabasin. Current. Research. Geol. Sur. Can., Pap. 85-1B 1985, 125-132. [CrossRef]

17. Barrett, T.J.; Fralick, P.W. Sediment redeposition in Archean iron formation: Examples from the Beardmore-Geraldton greenstone belt, Ontario. J. Sediment. Petrol. 1985, 55, 205-212.

18. Devaney, J.R. Sedimentology and Stratigraphy of the Northern and Central Metasedimentary Belts in the Beardmore-Geraldton Area of Northern Ontario. M.Sc. Thesis, Lakehead University, Thunder Bay, ON, Canada, 1987.

19. Barrett, T.J.; Fralick, P.W. Turbidites and iron formation, Beardmore-Geraldton, Ontario: Application of a combined ramp/fan model to Archean clastic and chemical sedimentation. Sedimentology 1989, 36, 221-234. [CrossRef]

20. Devaney, J.R.; Williams, H.R. Evolution of an Archean subprovince boundary: A sedimentological and structural study of part of the Wabigoon-Quetico boundary in northern Ontario. Can. J. Earth Sci. 1989, 26, 1013-1026. [CrossRef]

21. Williams, H.R. Subprovince accretion tectonics in the south-central Superior Province. Can. J. Earth Sci. 1990, 26, 570-581. [CrossRef]

22. Hart, T.R.; terMeer, M.; Jolette, C. Precambrian Geology of Kitto, Eva, Summers, Dorothea and Sandra Townships, Northwestern Ontario: Phoenix Bedrock Mapping Project; Open File Report 6095; Ontario Geological Survey: Sudbury, ON, Canada, 2002. 
23. Lafrance, B.; DeWolfe, J.C.; Stott, G.M. A sructural reappraisal of the Beardmore-Geraldton Belt at the southern boundary of the Wabigoon subprovince, Ontario, and implications for gold mineralization. Can. J. Earth Sci. 2004, 41, 217-235. [CrossRef]

24. Roedder, E. Fluid Inclusions. In Reviews in Mineralogy; Mineralogical Society of America: Washington, DC, USA, 1984; Volume 12, ISBN 0-939950-16-2.

25. Bodnar, R.J. Interpretation of data from aqueous-electrolyte fluid inclusions. In Fluid Inclusions: Analysis and Interpretation; Samson, I., Anderson, A., Marshall, D., Eds.; Short Course Series; Mineralogical Association of Canada: Ottawa, ON, Canada, 2003; Volume 32, pp. 81-100.

26. Diamond, L.W. Introduction to gas-bearing fluid inclusions. In Fluid Inclusions: Analysis and Interpretation; Samson, I., Anderson, A., Marshall, D., Eds.; Short Course Series; Mineralogical Association of Canada: Ottawa, ON, Canada, 2003; Volume 32, pp. 101-158. ISBN 0-921294-32-8.

27. Frape, S.K.; Fritz, P. Geochemical trends for groundwaters from the Canadian Shield. In Saline Water and Gases in Crystalline Rocks; Fritz, P., Frape, S.K., Eds.; Special Paper; Geological Association of Canada: St. John's, NL, Canada, 1987; pp. 19-38.

28. Borisenko, A. Study of the salt composition of solutions of gas-liquid inclusions in minerals by the cryometric method. Geol. Geofiz. 1977, 18, 16-27.

29. Linke, W.F. Ferric chloride decahydrate: the systems $\mathrm{FeCl}_{3}-\mathrm{H}_{2} \mathrm{O}$ and $\mathrm{FeCl}_{3}-\mathrm{HCl}-\mathrm{H}_{2} \mathrm{O}$ below 0. J. Phys. Chem. 1956, 60, 91-96. [CrossRef]

30. Wilkinson, J. MgCl- $\mathrm{H}_{2} \mathrm{O}$ System. Fluid-Inclusions@relay.doit.wisc.edu. 1998. Available online: www.geology. wisc.edu/flincs / fi/disc/loweutec2.html (accessed on 25 January 2018).

31. Cohen-Adad, R.; Lorimer, J.W. Alkali Metal and Ammonium Chlorides in Water and Heavy Water (Binary Systems); IUPAC Solubility Data Series; Pergamon Press: Oxford, UK, 1991; Volume 47.

32. Dubé, B.; Gosselin, P. Greenstone-hosted quartz-carbonate veins. In Mineral Deposits of Canada; Goodfellow, W.D., Ed.; Mineral Deposits Division Special Publication; Geological Association of Canada: St. John's, NL, Canada, 2007; ISBN 13: 978-1-897095-24-9.

33. Seward, T.M. Thio complexes of gold in hydrothermal ore solutions. Geochim. Cosmochim. Acta 1973, 37, 379-399. [CrossRef]

34. Renders, P.J.; Seward, T.M. The stability of hydrosulphido- and sulphido complexes of Au(I) and Ag(I) at $25^{\circ}$ C. Geochim. Cosmochim. Acta 1989, 53, 244-253. [CrossRef]

35. Shenberger, D.M.; Barnes, H.L. Solubility of gold in aqueous sulfide solutions from 150 to $350{ }^{\circ} \mathrm{C}$. Geochim. Cosmochim. Acta 1989, 53, 269-278. [CrossRef]

36. Benning, L.G.; Seward, T.M. Hydrosulphide complexing of $\mathrm{Au}(\mathrm{I})$ in hydrothermal solutions from $150-400{ }^{\circ} \mathrm{C}$ and 500-1500 bars. Geochim. Cosmochim. Acta 1996, 60, 1849-1871. [CrossRef]

37. Wood, S.A. Application of a multiphase ore mineral solubility experiment to the separation of base metal and gold mineralization in Archean greenstone terrains. Econ. Geol. 1987, 82, 1044-1048. [CrossRef]

38. Romberger, S.B. Transport and deposition of gold in hydrothermal systems. In Greenstone Gold and Crustal Evolution; Robert, F., Sheahan, P.A., Green, S.B., Eds.; NUNA Conference Volume; Geological Association of Canada, Mineral Deposits Division: St. John's, NL, Canada, 1991; pp. 61-66, ISBN 0-919216-43-9.

39. Phillips, G.N. Pressure-temperature environments and the causes of gold deposition. In Greenstone Gold and Crustal Evolution; Robert, F., Sheahan, P.A., Green, S.B., Eds.; NUNA Conference Volume; Geological Association of Canada, Mineral Deposits Division: St. John's, NL, Canada, 1991; p. 193, ISBN 0-919216-43-9.

40. Hu, F.F.; Fan, H.R.; Jiang, X.H.; Li, X.C.; Yang, K.F.; Mernagh, T. Fluid inclusions at different depths in the Shandandao gold deposit, Jiaodong Peninsula, China. Geofluids 2013, 13, 528-541. [CrossRef]

41. Bethke, C.M.; Marshak, S. Brine migrations across North America-the plate tectonics of groundwater. Annu. Rev. Earth Planet. Sci. 1990, 18, 287-315. [CrossRef]

42. Harper, D.A.; Longstaffe, F.J.; Wadleigh, M.A.; McNutt, R.H. Secondary K-feldspar at the Precambrian-Paleozoic unconformity, southwestern Ontario. Can. J. Earth Sci. 1995, 32, 1432-1450. [CrossRef]

43. Hassler, S.W.; Simonson, B.M. Deposition and alteration of volcaniclastic strata in two large, early Proterozoic iron-formations in Canada. Can. J. Earth Sci. 1989, 26, 1574-1585. [CrossRef]

44. Brown, P.E. Fluid inclusion modeling for hydrothermal systems. In Techniques in Hydrothermal Ore Deposits Geology; Richards, J.P., Larson, P.B., Eds.; Reviews in Economic Geology; Society of Economic Geologists: Littleton, CO, USA, 1998; Volume 10, pp. 151-171. 
45. Hendel, E.M.; Hollister, L.S. An empirical solvus for $\mathrm{CO}_{2}-\mathrm{H}_{2} \mathrm{O}-2.6 \mathrm{wt} \%$ salt. Geochim. Cosmochim. Acta 1981, 45, 225-228. [CrossRef]

46. Hedenquist, J.W.; Henley, R.W. The importance of $\mathrm{CO}_{2}$ on freezing point measurements of fluid inclusions: Evidence from active geothermal systems and implications for epithermal ore deposition. Econ. Geol. 1985, 80, 1379-1406. [CrossRef]

47. Roedder, E.; Bodnar, R.J. Geologic pressure determinations from fluid inclusion studies. Annu. Rev. Earth Planet. Sci. 1980, 8, 263-301. [CrossRef]

48. Phillips, G.N. Gold and alteration in the Golden Mile, Kalgoorlie. Econ. Geol. 1986, 81, 779-808. [CrossRef]

49. Zezin, D.Y.; Migdisov, A.A.; Williams-Jones, A.E. The solubility of gold in hydrogen sulfide gas: An experimental study. Geochim. Cosmochim. Acta 2007, 71,3070-3081. [CrossRef]

50. Zezin, D.Y.; Migdisov, A.A.; Williams-Jones, A.E. The solubility of gold in $\mathrm{H}_{2} \mathrm{O}-\mathrm{H}_{2} \mathrm{~S}$ vapour at elevated temperature and pressure. Geochim. Cosmochim. Acta 2011, 75, 5140-5153. [CrossRef]

51. Duan, Z.; Møller, N.; Weare, J.H. Equation of state for the $\mathrm{NaCl}-\mathrm{H}_{2} \mathrm{O}-\mathrm{CO}_{2}$ system: Prediction of phase equilibria and volumetric properties. Geochim. Cosmochim. Acta 1995, 59, 2869-2882. [CrossRef]

(c) 2018 by the authors. Licensee MDPI, Basel, Switzerland. This article is an open access article distributed under the terms and conditions of the Creative Commons Attribution (CC BY) license (http://creativecommons.org/licenses/by/4.0/). 